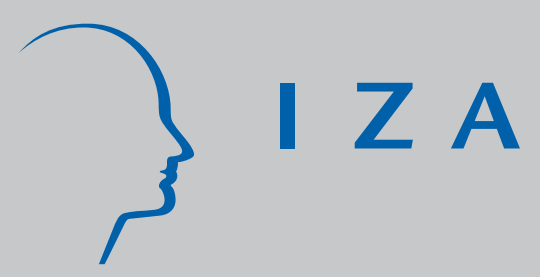

IZA DP No. 118

Improving Nurse Retention in the British National Health Service: The Impact of J ob Satisfaction on Intentions to Quit

Michael A. Shields

Melanie E. Ward

February 2000 


\title{
Improving Nurse Retention in the British National Health Service: The Impact of Job Satisfaction on Intentions to Quit
}

\author{
Michael A. Shields \\ PSERC, University of Leicester, England \\ Melanie E. Ward \\ IZA, Bonn, Germany \\ Discussion Paper No. 118 \\ February 2000 \\ IZA \\ P.O. Box 7240 \\ D-53072 Bonn \\ Germany \\ Tel.: +49-228-3894-0 \\ Fax: +49-228-3894-210 \\ Email: iza@iza.org
}

This Discussion Paper is issued within the framework of IZA's research area The Future of Work. Any opinions expressed here are those of the author(s) and not those of the institute. Research disseminated by IZA may include views on policy, but the institute itself takes no institutional policy positions.

The Institute for the Study of Labor (IZA) in Bonn is a local and virtual international research center and a place of communication between science, politics and business. IZA is an independent, nonprofit limited liability company (Gesellschaft mit beschränkter Haftung) supported by the Deutsche Post AG. The center is associated with the University of Bonn and offers a stimulating research environment through its research networks, research support, and visitors and doctoral programs. IZA engages in (i) original and internationally competitive research in all fields of labor economics, (ii) development of policy concepts, and (iii) dissemination of research results and concepts to the interested public. The current research program deals with (1) mobility and flexibility of labor markets, (2) internationalization of labor markets and European integration, (3) the welfare state and labor markets, (4) labor markets in transition, (5) the future of work, (6) project evaluation and (7) general labor economics.

IZA Discussion Papers often represent preliminary work and are circulated to encourage discussion. Citation of such a paper should account for its provisional character. 


\section{ABSTRACT \\ Improving Nurse Retention in the British National Health Service: The Impact of Job Satisfaction on Intentions to Quit ${ }^{\star}$}

In recent years the National Health Service (NHS) in Britain has experienced an acute shortage of qualified nurses. This has placed issues of recruitment and retention in the profession high on the political agenda. In this paper we investigate the determinants of job satisfaction for nurses, and establish the importance of job satisfaction in determining nurses' intentions to quit the NHS. We find that nurses who report overall dissatisfaction with their jobs have a $65 \%$ higher probability of intending to quit than those reporting to be satisfied. However, dissatisfaction with promotion and training opportunities are found to have a stronger impact than workload or pay. Recent policies, which focus heavily on improving the pay of all NHS nurses will only have limited success unless they are accompanied by, improved promotion and training opportunities. Better retention will, in turn, lead to reduced workload.

JEL Classification: J45, J63, I18

Keywords: Nurses, job satisfaction, quitting intentions, principal component analysis

Michael A. Shields

Public Sector Economics Research Centre

Department of Economic

University of Leicester

University Road, Leicester

England LE1 7RH

Tel.: +44 (116) 2525374

Fax: +44 (116) 2522908

Email:mas9@le.ac.uk

* The authors are grateful to Thomas Bauer, Rob Euwals, Magnus Lofstrom, Steve Pudney, Steve Thompson and Stephen Wheatley Price for comments and suggestions, and the PSI and Department of Health for providing access to the data. The usual disclaimer applies. 


\section{Introduction}

For many years the British National Health Service (NHS) has faced substantial difficulties both in recruiting school-leavers into the nursing profession and retaining existing nursing staff. The profession is often described in the media as being in a state of 'crisis', as demonstrated by a considerable shortage of trained nurses in many NHS hospital trusts. This has led to increased concern, both in the profession and within government, about whether the stock of trained nurses is adequate to meet the future health service needs of an ageing population (see Buchan et al., 1997; Department of Health, 1995; Seccombe and Smith, 1996, 1997).

The extent of the recruitment and retention problems are considerable. Between 1987 and 1995 intakes to nurse training fell from 19,600 to 14,200 per annum (Seccombe and Smith, 1997), while an investigation of the 1991 Census showed that only $68 \%$ of those of working age with nursing qualifications in England were actually working in the profession. The remainder were split between working in another profession (16\%) and out of paid work (15\%) (Lader, 1995). Turnover in the NHS currently stands at around 9\% per annum for registered nurses (RGNs), but is far higher for nurses who have recently completed their training (Gray and Phillips, 1992; Seccombe and Smith, 1997). Recent evidence on latent turnover supports these figures, with around $40 \%$ of nurses expecting to leave the NHS within the next three years (Beishon et al., 1996). The fact that turnover is highest for nurses under 30 years of age is an important economic issue considering the average cost of $£ 50,000$ that British taxpayers pay to train a RGN. Moreover, it costs around $£ 5,000$ for a hospital trust to replace a core staff nurse (Audit Commission, 1997).

The result of poor recruitment and retention is that many NHS hospitals have been forced to operate with vacancy rates for RGNs of up to $20 \%$, which in 1996 amounted to a national vacancy rate of around 6,600 whole-time posts (Review Body for Nursing Staff, 1997). More recent estimates place the nursing shortage closer to 15,000 (Hancock, 1999). In the worst cases, staffing shortages have caused ward and operating theatre closures (Audit Commission, 1997). Hospitals trusts have responded to these develops by increasingly relying upon nursing agencies and temporary bank nurses to meet their immediate staffing requirements, as well as recruiting directly from overseas. These trends have raised serious concerns about the quality of patient care in the NHS. 
The problems of recruitment and retention have a variety of origins. On the recruitment side, demographic changes have substantially reduced the number of school-leavers available for nurse training, this effect being heightened by the sharp increase in the numbers participating in higher education. The late 1980s also witnessed a significant change in the system of nursing education, which increased the educational qualifications required for entry into nursing and further reduced the pool of potential nurse recruits (Phillips, 1995). Changes in the structure of nurse training have also added directly to the problem of nurses shortages, by reducing the proportion of training spent on-thejob from $60 \%$ to $20 \%$ in favour of college-based education. These demographic and educational factors have been exacerbated by a general perception by British school-leavers that nursing is a comparatively low status occupation with poor pay and career development opportunities (Seccombe et al., 1994). The result of poor recruitment is that the intake into nurse training needs to double in the next decade just to maintain the NHS nursing workforce at its current level (Buchan et al., 1997).

The recognition of the increasing need for and dwindling supply of new entrants into nursing has focused attention on the retention of existing staff. Nurses working have since the introduction of the 'internal market' in the health care reforms of 1991, reported widespread demoralisation linked to increased workloads, excessive working hours and poor pay and promotion prospects (Seccombe et al., 1994; UNISON, 1996). In 1995, for example, $85 \%$ of staff nurses reported working excess hours (with 25\% working between 5 and 9 extra hours, and $15 \%$ working 10 or more extra hours) and nearly $80 \%$ of those working overtime gained no financial compensation (Seccombe et al., 1995). In a national survey of NHS nurses in 1994, Beishon et al. (1996) found that only 32\% were satisfied with their pay and just $20 \%$ with their promotion prospects. In terms of non-pecuniary job elements, less than one-in-three nurses reported to be satisfied with their workload and only one half were satisfied with their hours.

Overall these facts and figures paint a picture of a profession facing considerable difficulties, characterised by a diminishing supply of labour at a time of increased demand for nursing services. Recent policy attention aimed at improving nurse retention has focused on pay and working conditions. Yet little is known about the relative impact of these different factors on nurse job satisfaction and retention.

In this paper we investigate the impact that such policies may have on improving retention in the 
NHS. Firstly, we examine the factors that determine job satisfaction in the nursing profession. Specifically, we quantify the impact of individual, job and employer-related characteristics on job satisfaction amongst nurses for the first time. Secondly, we model the relationship between job satisfaction and intentions to quit the NHS. Here, Principal Component Analysis allows us to identify the relative effect of improved pay, increased promotion and training opportunities, reduced workload and better workplace relations (with colleagues and patients) on retention. Our data source is a large and unique national survey of NHS nursing staff collected in 1994. We adopt the methodology used by a small, but growing literature, that combines economics and psychology to investigate the causes of labour market behaviour. Overall, our aim is to identify effective ways in which the nursing profession, government and hospital trusts might promote retention by improving the job satisfaction of nurses.

The paper is set out as follows. In Section 2 we review the recent literature which has investigated the determinants of job satisfaction and the relationship between job satisfaction and quitting behaviour. Section 3 introduces our data source, describes the particular characteristics of our nurse sample, and provides a preliminary analysis of the relationship between job satisfaction and intentions to quit. Our models of job satisfaction and the corresponding results are discussed in Section 4. Section 5 presents a simple model of quitting and the empirical estimates. We conclude the paper in Section 6.

\section{Literature Review}

It is well-known that economists have in the past been reluctant to study job satisfaction due to the subjective nature of individual responses. This reluctance was based on the argument that survey responses may be influenced by individuals' differing interpretation of questions and measurement scales. Recent years, however, have seen a considerable growth in the number of studies which have investigated the determinants of job satisfaction. The key result from this literature is that individual responses concerning job satisfaction are strong predictors of labour market behaviour. In crosssectional studies job satisfaction has predicted quits, absenteeism (e.g. Clegg, 1983) and worker productivity (e.g. Mangione and Quinn, 1975; Tsang et al., 1991). This implies that although one worker's reported level of job satisfaction as 'very satisfied' may not be identical to the next worker's, 
he or she will be less likely to quit or have time away from work and be more productive than a worker with lower reported job satisfaction. Linking an individual's evaluation of job satisfaction to their subsequent behaviour, provides a strong justification for utilising subjective assessments of job satisfaction in explaining labour market behaviour.

\section{(i) The Determinants of Job Satisfaction}

The analysis of job satisfaction has been prompted by attempts to address the issues of industrial action, quitting and individual 'happiness' at work. Researchers have also been interested in the relationship between job satisfaction and productivity and pecuniary and non-pecuniary reward. Following the seminal work of Hamermesh (1977) and Freeman (1978) economic studies of job satisfaction can be divided into those considering the workforce as a whole (e.g. Clark, 1996; Clark and Oswald, 1996), those analysing professional groups such as lawyers (Laband and Lentz, 1998), nurses (Shields and Wheatley Price, 1999) and academics (Ward and Sloane, 1999), those which investigate the impact of personal characteristics such as race, gender, age or education (e.g. Bartel, 1981; Clark, 1995; Clark et al., 1996; Sloane and Williams, 1996b; Tsang et al., 1991), and those which analyse the effect of work-related characteristics such as trade union membership (Bender and Sloane, 1998; Borjas, 1979; Gordon and Denisi, 1995; Meng, 1990; Miller, 1990), self employment (Blanchflower and Oswald, 1998) and establishment size (Idson, 1990).

A number of important determinants of job satisfaction have been identified in the literature which may be helpful in the consideration of job satisfaction in nursing. Firstly, a variety of personal characteristics have been found to have significant effects on reports of job satisfaction including gender, race, age, marital status, children and education. The largest effects here are generally associated with gender and age. Females have been found to report higher levels of job satisfaction in the UK labour force using information from the British Household Panel Survey (BHPS; Clark, 1996; Clark and Oswald, 1996) and Social Economic Life Initiative Household Survey (SCELI; Sloane and Williams, 1996b). Previous evidence suggests that age follows either a linear or U-shaped relationship with respect to job satisfaction (see Clark et al., 1996, for a review), with older workers generally being more satisfied with their job. 
Another group of studies have concentrated on the investigation of comparison effects on job satisfaction (see for example, Cappelli and Sherer, 1988; Clark and Oswald, 1996; Hamermesh 1977; Hampton and Heywood, 1999; Sloane and Williams 1996a). That is, workers may have some idea of relative or 'comparison' income which enters their utility function. Therefore individual job satisfaction is not only affected by a worker's own absolute income level, but also by their income relative to some expected level or comparison group. Hamermesh (1977) concludes that much of the differential in (dis)satisfaction across workers is due to individuals' comparison of their present job with the benchmark opportunities open to them. Sloane and Williams (1996b) find that both absolute and comparative income have positive effects on the job satisfaction of men and women. Work by Clark (1995, 1996, 1997) and Clark and Oswald (1996) provides some evidence that expectations are affected by a worker's age, educational level and occupation. In the case of nursing we are interested to discover whether relatively low pay or depressed perceptions of the professional standing of NHS nursing increases the importance of pay comparisons.

A third determinant of job satisfaction stems from the differing job characteristics of workers. Hours of work, establishment size, union membership and occupation have been found to have significant effects on self-reported job satisfaction. Comparatively few studies have considered the effect of hours of work on employee happiness. In the case of nurses, it is important to quantify the impact of better working conditions on their job satisfaction levels.

Finally, Clark $(1996,1997)$ finds a significant effect of including 'work values', or worker's reports of which factors are important in their job, on job satisfaction. More specifically, workers who emphasise the importance of pay are associated with lower reports of job satisfaction whilst those who emphasise workplace relations are more likely to report high levels of job satisfaction. As nursing staff are generally regarded as low-paid, given their skills and qualifications, these variables will also allow us to investigate whether the non-pecuniary advantages of work can compensate for unfavourable pay.

\section{(ii) The Impact of Job Satisfaction on Quitting Behaviour}

Despite the large literature on job turnover (in particular for the nursing profession, see for recent studies Ahlburg and Brown Mahoney, 1996; Parker and Rickman, 1995; Phillips, 1995; Schumacher, 
1997: for a review of British literature Gray and Phillips, 1992, and for a US review Tai et al., 1998), and the growing literature on job satisfaction, studies examining the relationship between job satisfaction and quitting behaviour in economics are comparatively rare. There are a number of studies in the psychological literature ${ }^{1}$, but many of these studies suffer from small sample sizes with little conformity in the control variables used and problems associated with non-random samples (for a discussion see Clark et al, 1999).

One obvious reason for the absence of economic literature in this area is the lack of large sample longitudinal data which can be used to identify both job satisfaction at wave t-1 and job turnover between waves t-1 and t. The most notable exception is Freeman (1978), who uses panel data from the US Nation Longitudinal survey (NLS, 1966-71) and the Michigan Panel Survey of Income Dynamics (PSID, 1972-72). He finds that job satisfaction is a significant determinant of quitting and quantitatively more important than wages. This relationship has been confirmed by Akerlof et al. (1988) using the NLS Older men survey, and more recently by Clark (1999) and Clark et al. (1999) using data from the first five waves of the British Household Panel Survey (1991-1996) and the first ten waves of the German Socio-Economic Panel (1984-1993). These studies have robustly established that the causality runs from job satisfaction to quitting outcomes. A further advantage of panel data studies is that unobservable individual heterogeneity can be easily controlled for. However, it has been found that such controls do not significantly change the estimated parameters of the model. This important result suggests that cross-sectional estimates are robust to this issue (see Clark, 1999; Clark et al., 1999).

In the absence of appropriate panel data, an alternative approach for investigating the relationship between job satisfaction and quitting behaviour has been to use the responses from cross sectional survey questions asking participants about their future employment expectations or intentions (i.e. latent turnover). Gordon and Denisi (1995) find, using data from three public sector organisations in the US, that job satisfaction is negatively and significantly related to intentions to quit. Laband and Lentz (1998) confirm this finding using a sample of lawyers in the US. Due to the nature of our data

\footnotetext{
${ }^{1}$ McEvoy and Cascio (1985) and Carsten and Spector (1987) provide evidence from meta-analyses and Steel and Ovalle (1984), Hom et al (1992) and Warr (1998) review the literature.
} 
the approach we adopt is most similar to the latter study and is described in detail in Section $5 .^{2}$

\section{Data, Sample Characteristics and Preliminary Analysis}

\section{(i) Data}

Our data is drawn from the 1994 national survey of NHS nursing staff conducted by the Policy Studies Institute for the Department of Health. The data were gathered from postal questionnaire responses to a one-in-three stratified sample of permanent nursing staff from a set of 91 NHS employers in England. ${ }^{3}$ This survey represents the most comprehensive source of information concerning the state of the NHS nursing profession and contains a wide-range of information about the attitudes of nurses towards their jobs and more generally towards the NHS. It also contains information on a host of jobrelated and employer characteristics including nursing grade, years of nursing experience, age of first registration, size and type of employer and location. The final response rate was $62 \%$, which generated observations on 14,400 NHS nursing staff. This paper focuses on the 9625 nurses, aged between 21 and 60, who were qualified as either a State Enrolled (SEN - typically two years basic training) or Registered General (RGN) nurse (three years basic training).

\section{(ii) Sample characteristics}

The definitions and the mean values for the full set of explanatory variables used in our later statistical models are provided in Table A1 in Appendix 1. Here we highlight the most salient features of our sample which are likely to be important in determining job satisfaction in the NHS nursing profession.

Only $8.2 \%$ of the sample are male, whilst the average age is 39 . Over $16 \%$ of NHS nurses have a degree or higher diploma, $18.3 \%$ possess qualifications at 'A' level or equivalent and $50.7 \%$ have a qualification at 'O' level or equivalent. Staff nurses (grade C, D and E) account for $57.2 \%$ of NHS nurses, Charge Nurses and Ward Managers (grade F and G) another 36.9\%, whilst only 5.9\% of nurses occupy Senior Nurse and Nurse Manager (grade H and I) positions. The average number of hours worked per week is 33.5 , with $35.8 \%$ of nurses reporting to work part-time (less than 35 hours). Our

\footnotetext{
${ }^{2}$ Despite extensive search, the authors are unaware of any panel data for NHS nurses which contains information about job satisfaction and other nursing-related characteristics.

${ }^{3}$ Members of the ethnic minorities were deliberately over-sampled in order to gain statistically reliable data on their
} 
sample is spread across specialties with $40.7 \%$ working in general medicine and surgery, $19 \%$ in primary and community care, $7.5 \%$ in mental illness, $9.4 \%$ in care of the elderly, $12.2 \%$ in midwifery, $2.4 \%$ in mental handicap, $6.3 \%$ in paediatrics and $2.4 \%$ employed in other specialties.

Of the key job-related characteristics nearly $13 \%$ of nurses are currently participating in post-basic training, and the mean length of job tenure is 79 months. Almost $95 \%$ of our sample are members of a trade union or professional organisation. There are a variety of work patterns (many include night duties) with a fairly even distribution of nurses between them. Over $45 \%$ of nurses work a shift pattern that is not their preferred choice. However, $78 \%$ of nurses do report having some degree of control over their exact working shift or hours. NHS nurses are often required to participate in unpaid overtime $(9.5 \%)$, to undertake tasks that are generally below those expected in their grade (54.1\%), to act-up to a higher grade (7.9\%), to play an extended role in the workplace $(48.9 \%)$ and to be an assessor or mentor of student nurses (72.4\%). Nearly $40 \%$ of nurses believe that their current grade is not a fair reflection of the duties they undertake. Just over $96 \%$ of nurses reported entering the nursing profession in search of 'rewarding work', $87.5 \%$ for 'job security' reasons, $84.4 \%$ in order to 'help others in the community', $76.3 \%$ for 'promotion prospects', $65.5 \%$ for 'pay' and $47.7 \%$ for 'flexibility of working hours'. We examine the impact of these work values in explaining reported job satisfaction levels in our later analysis.

(iii) Preliminary Analysis

In the PSI survey each nurse was asked to rank their level of overall job satisfaction, as well as for thirteen separate aspects of the nursing job and work environment. A four-point ranking was used for each aspect with possible responses ranging from 'satisfied' (4), 'neither satisfied or dissatisfied' (3), 'dissatisfied' (2) to 'very dissatisfied' (1). The distributions of reported job satisfaction for the overall measure and the thirteen separate job aspects are provided in Table 1. It is clear that NHS nurses exhibit considerable dissatisfaction with their current employment, with only $49.7 \%$ of the sample reporting to be satisfied overall with their job. However, this aggregate measure of job satisfaction hides the general dissatisfaction nurses feels towards particular aspects of NHS nursing. The greatest 
levels of dissatisfaction are with respect to the amount of administration (only $12.7 \%$ reporting satisfaction), promotion prospects $(17.3 \%)$, employment security $(24.1 \%)$ and the amount of time available for clinical duties $(25.5 \%)$. However, it is clear that dissatisfaction is wide-spread with less than $50 \%$ of our sample reporting to be satisfied in 11 of the 13 job aspects. The two exceptions are relations with colleagues and relations with patients, where the majority of nurses report to be satisfied (79.4\% and $87.4 \%$, respectively).

\section{[Table 1 about here]}

To enable us to explore the relationship between job satisfaction and nurses' quitting behaviour, we use the responses to a question in the survey concerning what nurses expected their employment status to be in three years time. Of the fourteen possible responses, three indicate that nurses expect to remain in the NHS (in a better nursing job, the same job and grade, or the same job but at a lower grade), while the remainder focus on activities outside of the NHS (for example, nursing in the private sector, a non-nursing job, in full or part-time education, working overseas or raising a family). One potential problem with this measure of expected employment status is that respondents can provide multiple answers. Therefore, we have defined a 'STAYER' as a nurse who only indicates one or more of the three staying in the NHS options but nothing else, and we define a 'QUITTER' as a nurse who indicates one or more of the non-NHS activities but none of the 'STAYER' categories. The small number of nurses who indicate both a 'STAYER' and 'QUITTER' intention we then define as a 'QUITTER', since they have indicated some uncertainty about their future employment status in the NHS. $^{4}$

Table 2 provides the results of simple cross-tabulations between the level of job satisfaction reported for the 13 job aspects and QUITTER. It is clear that job satisfaction is strongly associated with quitting intentions, with nurses who are very dissatisfied being significantly more likely to report an intention to quit than their satisfied counterparts for each of our job satisfaction measures. Simply subtracting the percentage of nurses who are satisfied and reporting an intention to quit from the

\footnotetext{
${ }^{4}$ Over $80 \%$ of the sample only indicated one future employment intention. We have also re-calculated the figures in Table 2 excluding the small group of nurses who indicated both 'STAYER' and 'QUITTER' intentions, and found that our results are qualitatively unchanged.
} 
percentage who are very dissatisfied and reporting an intention to quit for each separate aspect of their job provides a first indication of the most important factors determining quitting behaviour of nurses in the NHS. In this respect, dissatisfaction with employment security (20.1 percentage point differential), promotion prospects (18.4), training opportunities (18.3), involvement in decision-making (17.9) and pay (16.2) appear to be particularly important. However, it is also noticeable from the table that over $40 \%$ of nurses reporting overall satisfaction with their job indicate an intention to leave the NHS in the next three years. This indicates that other factors are important in determining the quitting intentions of nurses. Therefore we attempt to control for differences in labour and non-labour market opportunities outside of the NHS in our statistical quitting models in Section 5.

[Table 2 about here]

\section{The Determinants of Job Satisfaction in NHS Nursing}

\section{(i) Empirical Framework}

The general framework adopted by the studies highlighted in Section 2, is to define an individual's utility from working as: ${ }^{5}$

$$
U=u(Y, H, R Y, I N D, J O B, E M P)
$$

where $Y$ is the absolute wage and $H$ is the number of hours worked. Utility from work is assumed to be positively related to wages and negatively related to working hours. RY is the wage which the worker believes she could earn if employed elsewhere (termed the 'relative' or 'comparison' wage). ${ }^{6}$ It is expected that the higher $R Y$ relative to $Y$, the lower will be $U$, and captures an effect that can be described as relative deprivation, envy, jealousy or inequity (Clark and Oswald, 1996). Variations in work based utility are additionally explained by differences in individual specific characteristics, IND, job characteristics, $J O B$, and employer characteristics, EMP (the later two vectors characterising the general work environment).

\footnotetext{
${ }^{5}$ This is nested in the 'total' utility function, $T U=t u(u(Y, H, R Y, I N D, J O B, E M P), v)$, where $u$ is utility from work and $v$ is utility from other sources and spheres of life (Clark and Oswald, 1996).

${ }^{6}$ The impact of relative wages on job satisfaction is comparatively unexplored by economists compared to the other elements in (2). This is probably due to the difficulty in deriving a relative wage measure. A more detailed discussion of the various psychological theories that provide the justification for including relative wages in job satisfaction models can be found in Clark and Oswald (1996).
} 
In this paper, we extend the elements in (1) as follows:

$$
U=u(Y, H, R Y, I N D, J O B, N U R S E, W V, E M P)
$$

where NURSE represents a vector of characteristics which are important in the NHS nursing profession and which are expected to be important in explaining variations in job satisfaction. Following Clark (1996), WV is a vector of individual specific work-values, which are assumed to be pre-determined and exogenous to current work-based utility. It is expected that these work values reflect the aspects of work which an individual attaches most priority too, and can be either precuniary (e.g. pay is important) or non-pecuniary (e.g. helping others is important) in nature.

In this context, the self-reported measure of overall job satisfaction contained in our data is taken to represent a direct proxy for $U$. Given the ordinal nature of this variables we estimate ordered probit models to determine the level of overall job satisfaction reported by individual nurses in terms of a latent variable $\left(s^{*}\right)$ and the observed job satisfaction level $(s)$ as follows:

$$
\begin{gathered}
s^{*}=\beta_{1}^{\prime} Y+\beta_{2}^{\prime} H+\beta_{3}^{\prime} R Y+\beta_{4}^{\prime} I N D 1+\beta_{5}^{\prime} J O B 1+\beta_{6}^{\prime} E M P 1+\beta_{7}^{\prime} N U R S E 1+\beta_{8}^{\prime} W V 1+v \\
s=h \text { if } T_{h-1}<s^{*}<T_{h} \quad h=I, \ldots, H-I \quad v \sim \mathrm{N}(0,1)
\end{gathered}
$$

where $\beta_{i}(i=1 \ldots 8)$ are vectors of parameters and $h$ denotes the level of job satisfaction. We code $s$ as: (1) VERY DISSATISFIED, (2) DISSATISFIED, (3) NEITHER SATISFIED NOR DISSATISFIED and (4) SATISFIED. Equation (3) then describes the individual's unobserved propensity for job satisfaction (utility from work), $s^{*}$, given the seven vectors of exogenous variables. The thresholds $\left(T_{0}\right.$ to $T_{h-1}$ ) provide the values of $s^{*}$ required for a given level of job satisfaction to be experienced, with a value of $s^{*}<T_{0}$ placing an individual nurse at the lowest level of job satisfaction. As $s^{*}$ increases one or more job satisfaction thresholds are crossed and the individual's job satisfaction increases. The model is estimated by Maximum Likelihood and identification is achieved by setting $T_{0}=0$ (See Davidson and MacKinnon, 1993, for further details).

We estimate two versions of the model. In the BASIC model we restrict the elements in vectors $\beta_{7}$ 
and $\beta_{8}$ to be zero, and following previous studies include controls for absolute wages, relative wages and number of hours worked. Given that remuneration for NHS nurses is based on a structured grading system, with nationally negotiated rates of pay at each grade, controls for absolute wages are entered as 7 dichotomous variables indicating each possible nursing grade. Our relative wage measure is analogous to that of Clark and Oswald (1996), but in our case is based on the wages of other public sector employees in Britain rather than the entire employee labor force, conditional on observable human capital characteristics. It was constructed using data from the UK's Quarterly Labor Force Survey (see Appendix 2 for details). The comparison with other public sector professions is pertinent since the whole debate about the relative pay of NHS is typically positioned with respect to the pay of public sector employees such as teachers, police and social workers.

The vector IND1 includes controls for age, gender, marital status, number of dependant children, ethnic minority background and level of education. The elements in vector JOB1 are being an enrolled nurse (SEN) relative to an registered nurse (RGN), nursing specialty, past and present training episodes, job tenure in current post (at current grade), shift pattern and trade union membership status. The type, size, and location of the NHS employer constitute EMP1.

This BASIC model is similar to that specified in the literature which has investigated the determinants of job satisfaction in the wider labour market, and the estimated parameters provide us with benchmark indicators of the most important determinants of job satisfaction for NHS nursing staff. If, however, the incidence of low job satisfaction is indicative of a workplace which offers employees a poor work environment in other respects, then this simple model may provide biased estimates of the effect of job and employer characteristics on job satisfaction. ${ }^{7}$ Thus in our EXTENDED model we additionally control for other key aspects of the NHS nursing work environment which are likely to impact on job satisfaction. The vector NURSE contains controls for being employed in a shift pattern which is not equal to the preferred pattern, having a degree of control over working hours, participating in unpaid overtime, undertaking work tasks below expected at each

\footnotetext{
${ }^{7}$ This is akin to the debate about the effect of trade union membership on job satisfaction. If workplaces characterised by high levels of trade union membership also have better general work environments, then the exclusion of variables describing other aspects of the work environment will give biased (upwards) estimates of the effect of union membership on job satisfaction. For example, Gordon and Denisi (1995) find that once controls are made for working conditions in job satisfaction models no significant effect of union membership on job satisfaction is found.
} 
grade, acting up to a higher grade, playing an extended role in the workplace, current grade being an unfair reflection of current nursing duties, being an assessor or mentor of student nurses, whether training and other human capital activities are encouraged in the workplace and having a second (typically nursing) job. Finally, in the EXTENDED model, we include variables which capture the pre-determined work values of individual nurses. These take the form of six dichotomous variables taking the value of 1 , respectively, if 'helping others', 'flexibility of working hours', 'rewarding work', 'job security', 'promotion prospects' and 'pay' is an important reason for why a nurse entered a career in nursing.

\section{(ii) Empirical Results}

Turning to the results for our BASIC model of overall job satisfaction in Table 3, we find that, similar to workers within other labour markets, the job satisfaction of nurses is significantly influenced by a number of individual characteristics. Age increases linearly with job satisfaction with older nurses being significantly more satisfied with their job overall than the excluded age group of under 25 year olds (e.g. the marginal probability of reporting to be satisfied (MP), for nurses under 25 compared to those over 50 , is -0.218$).{ }^{8}$ We identify a significant gender effect, with males reporting lower levels of overall job satisfaction than females ( $\mathrm{MP}=-0.137)$, and a significant effect of ethnicity, with Asians and Blacks reporting lower overall job satisfaction than the omitted category of whites. The latter result is likely to reflect the considerable discrimination that many ethnic minority nurses face in the NHS (Pudney and Shields, 2000; Shields and Wheatley Price, 1999). Interestingly, being married and number of children have positive effects on overall job satisfaction, although only the former is significant. Higher levels of qualification are associated with significantly lower levels of job satisfaction for British nurses, perhaps as individual expectations are adjusted upwards.

Consistent with theory, absolute wages (captured by our grading variables) are positively related to job satisfaction, whilst increased working hours negatively affect job satisfaction. Relative wages also exhibit a significant impact, with higher relative wages successively lowering reports of overall job satisfaction. Relatively low pay within the nursing profession, or depressed perceptions of professional 
standing, do therefore appear to promote the significance of pay comparison within nursing (in which case policy aimed at promoting the professional standing of nurses may have positive effects on overall job satisfaction). However, the absolute wage effect on overall job satisfaction is still quantitatively more important than the relative.

Enrolled nurses are significantly more satisfied than registered nurses, which may be the result of lower expectations in terms of pay and promotion due to their constrained promotion prospects. Those nurses currently undertaking post basic training are significantly more satisfied with their job overall than those not currently training, but satisfaction appears to decrease with number of training spells completed. Job satisfaction follows a U-shaped relationship with respect to tenure in current position. There is reasonable conformity in overall job satisfaction across specialisation, although those in paediatrics and primary and community care report significantly higher job satisfaction than those specialising in mental illness. Shift pattern has an important influence on overall job satisfaction with those working shifts which include night duties having lower job satisfaction levels than nurses working days only. We find no significant effect of union membership on the overall job satisfaction of nurses.

Finally, although we find no significant impact of establishment size on overall job satisfaction, type of employer is a significant determinant of nurses' overall job satisfaction. Those nurses working in general district hospitals report significantly lower job satisfaction than those working in NHS hospital trusts. Once job and work environment factors are accounted for, we find no significant evidence of regional variations in overall job satisfaction levels.

The results of our EXTENDED model are presented in the second column of Table 3. The effects of the extended job characteristics capturing NHS nursing work environment are all statistically significant and suggest that policies aimed at improving working conditions for nurses would be extremely influential in promoting job satisfaction in the profession. By far the largest negative determinant of overall job satisfaction is not being graded fairly in accordance with ones duties (Marginal probability of reporting overall job satisfaction $(\mathrm{MP})=-0.246$ ). This subjective comparison variable suggests that workers have an idea of relative grade which enters their utility function.

\footnotetext{
${ }^{8}$ The marginal probabilities are calculated holding all other characteristics at the sample mean.
} 
Individual job satisfaction is not only affected by a worker's own grade, but also by their grade relative to some expected level or comparison group. Much of the differential in (dis)satisfaction across nurses is therefore due to individuals' comparison of their present grade with benchmark opportunities open to them. Nurses undertaking tasks below their grade, undertaking duties which are typically undertaken by more senior nurses (an extended role) or those working unpaid overtime also report significantly lower levels of job satisfaction. It is evident that being duly recognised for one's activities is an extremely important influence on the overall job satisfaction of nurses and possibly results from nurse shortages requiring nurses to work more overtime or expand their duties around those traditionally associated with a particular grade. Some dissatisfaction may also originate from perceptions of poor career prospects, also an explanation for why those who are assessors or mentors of students and those nurses who hold a second nursing job might report significantly lower levels of job satisfaction. The largest positive effect on job satisfaction, however, originates from being within a workplace where training and other forms of human capital development are encouraged $(\mathrm{MP}=$ 0.182). Positive reinforcement and encouragement may be very important in promoting nurses' overall job satisfaction.

Another very large negative impact on nurses' job satisfaction is having to work a shift pattern not equal to one's preferred pattern $(\mathrm{MP}=-.163)$. With this finding emerges the suggestion that it is not so much the absolute number of normal working hours (no longer significant in the EXTENDED model), but rather the arrangement of these hours to suit an individual's preferences that is of critical importance in nurses' overall job satisfaction. The effects of working varying shift patterns on job satisfaction remain the same in the EXTENDED model, but having some control over the arrangement of hours and shifts has a significantly large and positive impact on overall job satisfaction $(\mathrm{MP}=$ .078). Better working conditions policy should focus in particular on the elements of recognition, duties and shift preferences in the nursing job.

The work values variables included in the EXTENDED model attempt to capture the aspects of work which an individual attaches most priority to and the effects of these aspects in the analysis of job satisfaction. Results reveal that those who stress the non-pecuniary aspects of the job, that is those for whom the flexibility of hours $(\mathrm{MP}=0.015)$ and helping others $(\mathrm{MP}=0.040)$ were principal 
reasons for entering the nursing profession, indicate significantly higher levels of overall job satisfaction. A preference for rewarding work has the largest effect, increasing the probability of reporting to be satisfied with their job by 0.103 . These aspects of a nursing career may therefore offer a positive compensating differential for e.g. lower pay, for these individuals. Those nurses emphasising the more pecuniary aspects of the job such as those attracted by job security $(\mathrm{MP}=-$ $.029)$, promotion prospects $(\mathrm{MP}=-0.044)$ or pay $(\mathrm{MP}=-0.033)$, report lower, although not significantly lower, levels of overall job satisfaction. These individuals' expectations are likely to have been most disappointed, but not to such an extend as to have any significant negative impact on determination of job satisfaction, at least for those who still work within the profession.

The remaining effects on job satisfaction within the EXTENDED model are on the whole unchanged to the results of the BASIC model, with a couple of notable exceptions. Firstly, the relationship between age and overall job satisfaction is now a strongly linear one. The youngest nurses - those under 25 - are significantly less satisfied with their job overall than the older nurses, with overall satisfaction increasing with age. Second, with the inclusion of the additional variables in the EXTENDED model, the ethnicity effect and the absolute income effect for the lowest grades becomes insignificant. Finally, the negative effect on overall job satisfaction of working for a general district hospital strengthens considerably. These results reflect the particular importance of work place and work value variables on job satisfaction for the ethnic communities and for the lowest paid and youngest workers within the nursing profession. Policies aimed at improving working conditions of nurses in the NHS would be most efficiently targeted at these groups.

\section{The Impact of Job Satisfaction on Intention to Quit in NHS Nursing}

\section{(i) A Simple Model of Quitting Intentions}

Given the cross-sectional nature of our data, the model of quitting behaviour we estimate is most similar to Laband and Lentz (1998). Since we are not able to track nurses over a period of time and observe their actual quitting behaviour, we use information on nurses' intentions to quit in the three years following interview. The question which then arises is 'How good a predictor of actual quitting is intended quitting'? To answer this question we rely on a small longitudinal study of NHS nurses 
conducted by Mercer (1979). Although dated, Mercer found that quitting intentions were the strongest predictor of actual turnover, with over $83 \%$ of the $17 \%$ of nurses reporting an intention to quit having done so within the following year. Steel and Ovalle (1984) also provide some confirmation of this evidence more generally, using a meta-analysis of the large number of psychology studies that have examined the relationship between behavioural intentions and employee turnover.

Considering the dichotomous nature of our quitting variable (i.e. STAYER $=0$, QUITTER $=1$ ) we estimate a binary probit model in order to calculate the probability of nurses intending to leave the NHS in the three years following interview. We assume that intentions to quit are a function of current job satisfaction (or utility from work) and vectors of individual and work-related characteristics, which aim to capture the labour and non-labour market opportunities available to our sample outside of the NHS. ${ }^{9}$

We estimate two versions of the model. In Model 1, we include controls for job satisfaction as simply three dummy variables indicating overall satisfaction, neither satisfied or dissatisfied, and dissatisfied (with very dissatisfied acting as the reference category). This has the benefit of providing a direct estimate of the impact of job satisfaction on quitting intentions. However, the disadvantage of this approach is that it tells us little about which specific aspects of the job nurses place priority on when considering their future employment options. Disentangling and ranking these aspects is central to informing the design of policy aimed at improving nurse retention. In the context of the wider labour market, Clark (1999) has found, using data from the British Household Panel Survey, that satisfaction with job security and the work itself are more important than satisfaction with hours of work or pay in determining labour turnover.

In Model 2 we address this issue using Principal Component Analysis (PCA), in order to summarise in a meaningful way the job satisfaction responses for the thirteen separate aspects of nursing described in Section 3. The objective of PCA is to find the unit-length linear combinations of these variables with the greatest variance i.e. to identifying underlying factors which contain most of the information contained in the thirteen variables (see Lawley and Maxwell, 1971 for further details).

\footnotetext{
${ }^{9}$ One general criticism of this study, as well as those highlighted in Section 2(ii), is that if it is the case that the most dissatisfied workers have already have left their job, estimates of the effect of job satisfaction on quitting outcomes will be biased downwards. Our results, therefore, should be interpreted as providing a lower-bound estimate.
} 
Following standard practice we retained only those components (out of the 13) which have eigenvalues greater than 1, regarding the others as sampling noise in the data. The practical benefit of this procedure is that the extracted components can be included as orthogonal covariates in the quitting model, as opposed to including thirteen separate measures of job satisfaction which are likely to be highly correlated.

The results clearly suggest that there are common dimensions in the job satisfaction measures. Five components were retained in the analysis, and the proportion of the variance in the data explained by them (the so called 'communality') is consistently above $50 \%$, and is over $70 \%$ for basic pay, time for clinical duties, auxiliary nursing support and relations with patients. The sole exception is flexibility of working hours with communality around 37\%. Examining the aspects of the job that load most heavily onto each of the components enables us to gain an idea as to what 'unobservable' characteristic each represents. Satisfaction with regard to two job aspects loaded most heavily onto the first component: satisfaction with promotion prospects and training opportunities. We term this component, satisfaction with career advancement opportunities. The second component is dominated by satisfaction with present workload, amount of administration and time for clinical duties. These three aspects clearly represent how happy nurses are with workload related aspects of their job. Two job aspects load most heavily on the third factor: relations with colleagues and relations with patients. We refer to this component as workplace relations. Component four is dominated by concerns about pay, and satisfaction with respect to qualified and auxiliary staff load most heavily onto component five. Using the resulting loading factors and the individual specific responses to the thirteen job satisfaction questions we construct, for each nurse, five composite satisfaction variables which we include as explanatory variables in our model.

The vector of individual characteristics, which we include as covariates in our two models, are age, gender, marital status, number of dependent children and level of formal educational qualifications. Each of which is expected to be important in determining the number of labour and non-labour market opportunities available to nurses outside of the NHS. In particular, we expect that younger nurses would have a greater number of labour market openings available to them, and that females would have more non-labour market opportunities than males. Similarly, the more highly 
educated are likely to have greater occupational mobility than the less educated.

In order to capture as much variation in intentions to quit as possible, we also include a number of job-related characteristics which may be important in determining the amount of outside opportunities available to NHS nursing staff. Thus we include controls for nursing seniority, nursing specialty, hours worked and tenure in current post. Since senior and manager nursing grades require a considerable amount of nursing-specific human capital investment (in the forms of on-the-job experience and postbasic training), which might not be rewarded in other professions, then we would expect that highly trained nurses would be less likely to quit the NHS than more junior nurses. However, it is also the case that a substantial component of senior nurses' job tasks are management related, which are general skills applicable to many areas of the labour market and hence potentially increasing their likelihood of intending to quit the NHS. Finally, we control for type and size of NHS employer, and include eight regional dummy variables to capture geographical differences in labour market opportunities.

\section{(ii) Empirical Results}

Table 4 provides the estimates for our intentions to quit probit model, together with the marginal effects calculated holding all other variables at their sample mean values.

Before we discuss these results it is important to address the issue of endogeneity highlighted in Section 2(ii). So far, we have assumed that the error terms of the job satisfaction and intentions to quit model are not significantly correlated i.e. there is no unobservable individual heterogeneity which simultaneously determines job satisfaction and intentions to quit. ${ }^{10}$ To provide a simple test of the robustness of our findings to possible endogeneity concerns we simultaneously estimate job satisfaction and intentions to quit using a bivariate probit framework. Since this model requires two binary outcomes, we collapsed our ordered job satisfaction measure into a SATISFIED variable that takes the value 1 if a nurse reports satisfaction with her job, and 0 otherwise. Using the eight regional dummy variables (which are all insignificant in the job satisfaction model) as identification

\footnotetext{
${ }^{10}$ For example, nurses who are experiencing poor physical or mental health, which is unobserved in the survey, may have both a low propensity for job satisfaction and a high likelihood of intending to quit. In this case, the coefficients on the job satisfaction indicators in the quitting model would capture not only the effect of job satisfaction on quitting intentions but
} 
restrictions, we find evidence of some correlation in the residuals terms (at the $10 \%$ level of significance) but allowing for this does not significantly effect our estimates of the impact of job satisfaction on intentions to quit provided below. ${ }^{11}$ This conclusion is supported by Clark et al. (1999) who find that the relationship between job satisfaction and quitting found in cross-sectional studies is robust to concerns about unobserved individual heterogeneity.

Turning to Table 4, the first column presents the results for Model 1, including the three dummy variables for overall job satisfaction. These variables, which provide a direct estimate of the impact of job satisfaction on quitting intentions, reveal overall job satisfaction to be the single most important determinant of intentions to quit among NHS nurses. Those individuals reporting to be very dissatisfied with their job overall are $65 \%$ more likely to hold intentions to quit than those reporting to be satisfied, with the probability of intending to quit decreasing with successively higher job satisfaction.

The significance of individual characteristic variables in the quitting model suggest that alternative career opportunities will be of greater importance for some groups of nurses than others. Consistent with earlier work, our model predicts turnover to be greatest for nurses under the age of thirty. The relationship between age and intention to quit is U-shaped with older workers being significantly less likely to report an intention to quit over the next 3 years than the under 24 year olds. This 'stayer' effect is largest for the over 40s and in line with our expectations that younger nurses, who are in the early stages of their career, will most likely have a greater number of labour market openings available to them (and have less nursing specific human capital). We find no significant effect of gender on intentions to quit the nursing profession, but Asians and Blacks reveal a higher probability of moving away from the profession than whites, consistent with reports of discrimination in the NHS (Pudney and Shields, 2000; Shields and Wheatley Price, 1999). Being married has no significant effect on intentions to quit, but the relationship between quitting intensions and the number of children is Ushaped with those nurses with more than four children reporting higher intentions to quit. Finally, educational level is positively related to intentions to quit, consistent with our hypothesis that the more

${ }^{11}$ For brevity the results from these additional models are not presented. They are available from the authors on request. 
highly educated are likely to have greater occupational mobility than the less educated.

Alternative career opportunities are also found to be important for senior and manager nursing grades. Despite their perhaps very specialised human capital, we find that nurses working at grade $G$ and above are significantly more likely to voice quitting intentions than the excluded grade E, perhaps an indication that their managerial skills are valued on the general labour market. A number of other job characteristics are also found to be significant determinants of nurses' intentions to quit. The number of hours worked is U-shaped in relation to quitting intentions. Those working in the specialties of medical/surgery, midwifery and primary and community have a significantly higher probability of intending to quit than the excluded specialisation mental illness. Tenure has a U-shaped relationship with quitting intentions (turning point $=92$ months or 7.7 years), although the magnitude of this effect is very small.

These results confirm the importance of job satisfaction in determining intentions to quit, and also highlight particular groups of nurses for who outside opportunities are greatest. These are specifically the youngest nurses, the most highly educated and those nurses working in the highest grades. These groups of workers also make up some of the most valuable to the nursing profession, in that they represent the most experienced and the new stock of freshly trained talent.

The results for Model 2 are presented in column three of Table 4. Four of the five job satisfaction components included in the model: career advancement opportunities, workload, workplace relations and pay, are statistically significant. The remaining effects are unchanged across the two models. The components variables have a collectively smaller effect than the overall job satisfaction dummies, but are interesting in that they highlight which specific aspects of job satisfaction nurses place priority on when considering their future employment. Our results confirm previous suggestions of demoralisation within the profession linked to poor career advancement opportunities, increased workload and pay. We have also found that workplace relations (with staff and patients) are important in explaining variations in quitting intentions. The largest negative influence, however, is found for dissatisfaction with career advancement opportunities, which has a quantitatively far stronger impact than pay or 
workload. ${ }^{12}$ These results suggest that recent policies which have focused on improving pay in the profession will only have limited success unless they are accompanied by improved promotion and training opportunities. The latter are likely to involve changes to the current NHS grading structure.

Using the sample means and the estimated marginal probabilities from our models we can calculate the quantitative effect that improving overall levels of job satisfaction would have in reducing nurse turnover. Under the 'realistic' assumption, that $60 \%(80 \%)$ of those nurses indicating an intention to quit would have actually left the NHS in the following three years, policy initiatives which shifted all those nurses reporting to be 'very dissatisfied' or 'dissatisfied' to being 'neither satisfied or dissatisfied' would have the effect of retaining $8.1 \%(10.8 \%)$ of NHS nurses. Given a total NHS nursing workforce of 453,366 in 1994 (OHE, 1999), and assuming that our sample is representative of the whole profession, this is equivalent to retaining $36,838(49,118)$ nurses who would have left the NHS otherwise. A more 'optimistic' scenario, where all nurses would report to be satisfied with their job, would reduce nurse turnover by $82,171(109,561)$ which is equal to $18.1 \%(24.2 \%)$ of the total NHS nursing workforce. Given the $£ 5000$ it costs a NHS hospital trust to replace a core staff nurse (Audit Commission, 1997), improved job satisfaction will reduces total turnover costs by between $£ 184$ and £548 million.

\section{Conclusion}

There is currently an acute shortage of qualified nursing staff in NHS hospitals. The most recent estimates place this shortage at 15,000 FTE posts, with is the result of both a failure to attract sufficient numbers of school-leavers into the profession and poor retention of existing qualified nurses. In this paper we focus on the retention problem and address the question of how to improve the longterm supply of trained nurses in the NHS. We do this by examining the factors which determine job satisfaction for NHS nurses, and the impact that job satisfaction has on nurses' intentions to quit. Data is drawn from a large and unique national survey of NHS nursing staff collected in 1994, and we adopt the methodology of a small but growing literature which combines economics and psychology to

\footnotetext{
${ }^{12}$ The finding that career advancement opportunities have a greater effect than pay may be partly explained by the female dominance of this profession i.e. a large proportion of female nurses are second earners in the household.
} 
investigate the causes of labour market behaviour.

We find evidence of considerable disenchantment in the profession, which is manifested in low levels of job satisfaction being reported by nurses for most aspects of their job. Dissatisfaction with work, however, is significantly greater for young, male, ethnic minority and highly educated NHS nurses. The finding that low levels of job satisfaction are concentrated in the newly qualified (young) nursing staff is particularly important in focusing future policy initiatives. We find evidence that nurses' perceptions of 'relatively' low pay, compared to other public sector employees, leads to a significant deterioration in job satisfaction. In contrast, absolute pay is positively related to job satisfaction. We also find that the 'quality' of the working environment for nurses is extremely important in explaining variations in job satisfaction. In particular, working a shift pattern which is not your preferred, not being graded fairly in accordance with ones duties and undertaking unpaid overtime significantly reduces job satisfaction, while currently participating in post-basic training, being at a workplace which encourages human capital development and having some say over your working hours significantly increases job satisfaction. We find no evidence that job satisfaction is affected by either employer size or location, but nurses working in General District Hospitals report lower job satisfaction than other NHS employers.

Our results provide strong evidence that job satisfaction is the single most important determinant of intentions to quit among NHS nurses. Those individuals reporting to be very dissatisfied with their job overall are $65 \%$ more likely to hold an intention to quit than those reporting to be satisfied. The results also suggest that job satisfaction may be generally more important than the attraction of outside labour and non-labour market opportunities in the determination of quitting outcomes. Principal Component Analysis based on nurses' satisfaction with respect to thirteen aspects of their job, shows that demoralisation linked to poor career advancement opportunities, increased workload, pay and workplace relations are all important in determining quitting outcomes, but that dissatisfaction with career advancement opportunities has the largest quantitative affect.

Overall these findings suggest that recent policy attention aimed at improving nurse retention may be successful in that it has focused heavily on improved pay for all nurses. However, the evidence presented here suggests that efficient policy design must also concentrate on improving the career 
advancement opportunities available to nurses (e.g. which may require changes in the current nurse grading structure). The resulting improvement in retention would in turn reduce workloads. Special emphasise should also be placed on the needs of young and ethnic minority nurses who are particularly vulnerable to low levels of job satisfaction. We have calculated that successful policy initiatives, which improved overall job satisfaction in the profession, would reduce nurse turnover by over 36,000 nurses in the next three years. This is equivalent to around $8 \%$ of the NHS nursing workforce, and would save the NHS between $£ 184$ and $£ 548$ million in turnover costs. 
Table A1: Sample Means ( $\mathrm{n}=9625)$

\begin{tabular}{|c|c|c|}
\hline Explanatory Variables & Mean & S.E. \\
\hline \multicolumn{3}{|l|}{ Individual Characteristics } \\
\hline Age $<25$ (base category) & 0.036 & 0.002 \\
\hline Age 25-29 & 0.169 & 0.004 \\
\hline Age 30-34 & 0.212 & 0.004 \\
\hline Age 35-39 & 0.163 & 0.004 \\
\hline Age $40-44$ & 0.130 & 0.003 \\
\hline Age 45-49 & 0.129 & 0.003 \\
\hline Age $>50$ & 0.161 & 0.004 \\
\hline Male & 0.082 & 0.003 \\
\hline White (base category) & 0.842 & 0.006 \\
\hline Asian & 0.032 & 0.002 \\
\hline Black & 0.046 & 0.002 \\
\hline Other & 0.080 & 0.003 \\
\hline Married & 0.747 & 0.004 \\
\hline Degree or equivalent & 0.161 & 0.004 \\
\hline 'A' level or equivalent & 0.183 & 0.004 \\
\hline 'O' level or equivalent & 0.507 & 0.005 \\
\hline No qualifications (base category) & 0.146 & 0.003 \\
\hline Number of dependant children under 16 & 0.714 & 0.010 \\
\hline \multicolumn{3}{|l|}{ Wages and Hours } \\
\hline Grade I (Senior nurse / nurse manager) & 0.015 & 0.001 \\
\hline Grade H (Senior nurse / nurse manager) & 0.044 & 0.002 \\
\hline Grade $\mathrm{G}$ (Charge nurse / ward manager) & 0.233 & 0.004 \\
\hline Grade F (Charge nurse / ward manager) & 0.136 & 0.004 \\
\hline Grade E (Staff nurse) (base category) & 0.300 & 0.005 \\
\hline Grade D (Staff nurse) & 0.236 & 0.004 \\
\hline Grade C (Staff nurse) & 0.036 & 0.002 \\
\hline Relative wage $(\mathfrak{f})$ & 5.181 & $0.005)$ \\
\hline Number of hours worked per week & 33.489 & 0.083 \\
\hline \multicolumn{3}{|l|}{ Basic Job Characteristics } \\
\hline Enrolled nurse (SEN) & 0.165 & 0.004 \\
\hline Mental illness (base category) & 0.075 & 0.003 \\
\hline Mentally handicapped & 0.024 & 0.002 \\
\hline Medical / surgical & 0.407 & 0.005 \\
\hline Midwifery & 0.122 & 0.003 \\
\hline Care of the elderly & 0.094 & 0.003 \\
\hline Paediatrics & 0.063 & 0.003 \\
\hline Primary and community & 0.190 & 0.004 \\
\hline Other & 0.024 & 0.002 \\
\hline
\end{tabular}




\begin{tabular}{|c|c|c|}
\hline Currently doing post-basic training & 0.129 & 0.003 \\
\hline Number of completed training spells & 0.911 & 0.011 \\
\hline Tenure in current post (in months) & 79.151 & 0.766 \\
\hline Mix earlies, lates and nights & 0.298 & 0.005 \\
\hline Days only (base category) & 0.274 & 0.005 \\
\hline Mix of earlies and lates (no nights) & 0.121 & 0.003 \\
\hline Nights only & 0.213 & 0.004 \\
\hline Other shift pattern & 0.093 & 0.003 \\
\hline Member of trade union & 0.945 & 0.002 \\
\hline \multicolumn{3}{|l|}{ Extended Job Characteristics } \\
\hline Actual $\neq$ Preferred shift & 0.454 & 0.005 \\
\hline Has some control over shift/hours & 0.777 & 0.004 \\
\hline Undertakes unpaid overtime & 0.095 & 0.003 \\
\hline Undertakes tasks below grade & 0.722 & 0.005 \\
\hline Acting up to a higher grade & 0.079 & 0.003 \\
\hline Plays an extended role & 0.489 & 0.005 \\
\hline Assessor or mentor of students & 0.724 & 0.005 \\
\hline Grade not a fair reflection of duties & 0.387 & 0.005 \\
\hline Training encouraged at workplace & 0.410 & 0.005 \\
\hline Has a second nursing job & 0.206 & 0.004 \\
\hline \multicolumn{3}{|l|}{ Work Values } \\
\hline Helping others important & 0.844 & 0.004 \\
\hline Flexibility of working hours important & 0.477 & 0.005 \\
\hline Rewarding work important & 0.961 & 0.002 \\
\hline Job security important & 0.875 & 0.004 \\
\hline Promotion prospects important & 0.762 & 0.004 \\
\hline Pay important & 0.655 & 0.005 \\
\hline \multicolumn{3}{|l|}{ Employer Characteristics } \\
\hline General District Hospital & 0.214 & 0.004 \\
\hline Family Health Service Authority & 0.033 & 0.002 \\
\hline NHS Hospital Trust (base category) & 0.722 & 0.005 \\
\hline Employer size (number of nursing staff) & 1394.674 & 6.613 \\
\hline North Thames & 0.147 & 0.004 \\
\hline South Thames & 0.159 & 0.004 \\
\hline South & 0.070 & 0.003 \\
\hline Trent (base category) & 0.089 & 0.003 \\
\hline West Midlands & 0.148 & 0.004 \\
\hline East Anglia and Oxford & 0.088 & 0.003 \\
\hline North and Yorkshire & 0.124 & 0.004 \\
\hline North West & 0.125 & 0.004 \\
\hline Other region & 0.051 & 0.002 \\
\hline
\end{tabular}




\section{Appendix 2: Derivation of Comparison Wage Measure}

In order to calculate our measure of the 'comparison' wage for NHS nurses (i.e. what a nurse might expect to earn, on average, if employed in a comparable public sector profession) we have used data from the Quarterly Labour Force Survey (QLFS) of the United Kingdom undertaken in the Spring of 1994 (matching the date of the nursing survey). The QLFS, introduced in 1992, is a nationally representative survey whose principal aim is to produce a set of national (and regional) labor market statistics (mainly unemployment figures) for use by government departments. Each quarter approximately 64,000 households are surveyed eliciting information on some 160,000 individuals over the age of 16. A panel element is incorporated into the QLFS with each individual being interviewed over five successive quarters. Information on wages is only obtained from those about to leave the survey (or $20 \%$ of each quarters' sample). Selecting individuals in aged 21 to 60, in public sector employment (PUBLIC=2), in wave 5 (THISWV = 5), we obtained a sample of 1876 individuals. A comparison wage measure was constructed by estimating a simple log weekly wage regression for our sample of public sector employees, controlling for age (and age squared), gender, ethnicity, marital status and highest qualification and part-time status. Using the estimated parameters from this model, we mapped the predicted weekly wage, conditional on the same set of individual characteristics, into the nursing sample. This provides us with a continuous measure of the 'comparison wage', which we include as an additional covariate in the ordered probit job satisfaction models.

\section{References}

Ahlburg, D., Brown Mahoney, C., 1996. The Effects of Wages on the Retention of Nurses. Canadian Journal of Economics 29, S126-129.

Akerlof, G. A., Rose, A. K., Yellen, J. Y., 1988. Job Switching and Job Satisfaction in the US. Labor Market Brookings Papers on Economic Activity 2, 495-582.

Audit Commission, 1997. Finders, Keepers. The Management of Staff Turnover in the NHS Trusts. Audit Commission, London.

Bartel, A. P., 1981. Race Differences in Job Satisfaction: A Reappraisal. Journal of Human Resources 16, 295-303.

Beishon, S., Virdee, S., Hagell, A., 1995. Nursing in a Multi-Ethnic NHS. Policy Studies Institute, London.

Bender, K., Sloane, P. J., 1998. Job Satisfaction, Trade Unions and Exit-Voice Revisited. Industrial and Labor Relations Review 51, 220-240.

Blanchflower, D., Oswald, A. J., 1998. What makes and Entrepreneur? Journal of Labor Economics $16,26-60$. 
Borjas, G. J., 1979. Job Satisfaction, Wages and Unions. Journal of Human Resources XIV, 1, 21-40.

Buchan, J., Seccombe, S., Smith, G., 1997. The UK Nursing Labour Market. Unpublished report for the Royal College of Nursing.

Cappelli, P., Sherer, P., 1988. Satisfaction, Market Wages and Labor Relations: An Airline Study. Industrial Relations 27, 556-73.

Carsten, J., Spector, P., 1987. Unemployment, Job satisfaction and Employee Turnover: A MetaAnalytic Test of the Muchinsky Model. Journal of Applied Psychology 72, 374-381.

Clark, A. E., 1995. Is Utility Relative? Evidence from Household Data, DELTA, Paris.

Clark, A. E., 1996. Job Satisfaction in Britain. British Journal of Industrial Relations 34, 189-218.

Clark, A. E., 1997. Job Satisfaction and Gender: Why are women so Happy at Work? Labour Economics 4, 341-372.

Clark, A. E., 1999. What Really Matters in a Job? Hedonic Measurement using Quit Data. Mimeo, Universite d' Orleans.

Clark, A. E., Oswald, A. J., 1996. Satisfaction, and Comparison Income. Journal of Public Economics 61, 359-382.

Clark, A., Georgellis, Y., Sanfey, P., 1999. Job Satisfaction, Wage changes and Quits: Evidence from Germany. Research in Labor Economics, forthcoming.

Clark, A. E., Oswald, A. J., Warr, P,. 1996. Is Job Satisfaction U-shaped in Age? Journal of Occupational and Organizational Psychology 69, 57-81.

Clegg, C. W., 1983. Psychology of Employee Lateness, Absence and Turnover: A Methodological Critique and an Empirical Study. Journal of Applied Psychology 68, 88-101.

Department of Health, 1995. NHS Workforce in England, 1982-1992. HMSO, London.

Freeman, R. B., 1978. Job Satisfaction as an Economic Variable. American Economic Review 68, 135-141.

Gordon, M., Denisi, A., 1995. A Re-examination of the Relationship between Union membership and Job Satisfaction. Industrial and Labor Relations Review 48, 222-36.

Gray, A., Phillips, V., 1992. Explaining NHS staff Turnover: A Local Labour Market Approach, London School of Hygiene and Tropical Medicine. Final Report from Department of Health, London.

Hamermesh, D. S., 1977. Economic Aspects of Job Satisfaction. In: O. E. Ashenfelter, and W. E. Oates, eds., Essays in Labor Market Analysis. John Wiley, New York.

Hampton, M., Heywood, J., 1999. The Determinants of Perceived Underpayment: The Role of Racial Comparisons. Review of Social Economy 57, 141-155.

Hancock, R., 1999. Report of the RCN Autumn Conference. $20^{\text {th }}$ October 1999, Secretary General of the RCN.

Hom, P., Carannikas-Walder, F., Prussia, G., Griffeth, R., 1992. A Meta-Analytic Structural Equations Analysis of a Model of Employee Turnover. Journal of Applied Psychology 77, 
809-909.

Idson, T. L., 1990. Establishment Size, Job Satisfaction and Structure of Work. Applied Economics $11,4,606-28$.

Laband, D., Lentz, B., 1998. The Effects of Sexual Harassment on Job satisfaction, Earnings, and Turnover among Female Lawyers. Industrial and Labor Relations Review 51, 594-607.

Lader, D., 1995. Qualified Nurses, Midwives and Health Visitors. HMSO, London.

Lawley, D. N., Maxwell, A. E., 1971. Factor Analysis as a Statistical Method. $2^{\text {nd }}$ edn, Butterwoths, London.

Mangione, T. W., Quinn, R. P., 1975. Job Satisfaction, Counterproductive Behaviour and Drug use at work. Journal of Applied Psychology 60, 114-16.

McEvoy, G. M., Cascio, W. F., 1985. Strategies for Reducing Employee Turnover; A Meta-Analysis. Journal of Applied Psychology 70, 342-53.

Meng, R., 1990. The Relationship between Unions and Job Satisfaction. Applied Economics 22, $1635-48$

Mercer, G., 1979. The Employment of Nurses: Nursing Labour Turnover in the NHS. Croom Helm, London.

Miller, P., 1990. Trade Unions and Job satisfaction. Australian Economic Papers 29, 226-248.

OHE, 1997. Compendium of Health Statistics. 10 ${ }^{\text {th }}$ edn, Office of Health Economics, London.

Parker, C., Rickman, B., 1995. Economic Determinants of the Labour Force withdrawal of Registered Nurses. Journal of Economics and finance 19, 17-26.

Phillips, V. L., 1995. Nurses' Labor Supply: Participation, Hours of Work, and Discontinuities in the Supply Function. Journal of Health Economics 14, 567-582.

Pudney, S. E., Shields, M. A. (2000). Gender, Race, Pay and Promotion in the British Nursing Profession: Estimation of a Generalised Ordered Probit Model. Journal of Applied Econometrics, forthcoming.

Review Body for Nursing Staff, Midwives, Health Visitors and Professions Allied to Medicine, 1997. Fourteenth Report on Nursing Staff, Midwives and Health Visitors. HMSO, London.

Schumacher, E., 1997. Relative Wages and Exit Behaviour among Registered Nurses. Journal of Labor Research 18, 581-91.

Seccombe, I., Smith, G., 1996. In the Balance: Registered Nurse Supply and Demand. The Institute for Employment Studies, Brighton.

Seccombe, I., Smith, G., 1997. Taking Part: Registered Nurses and the Labour Market in 1997. The Institute for Employment Studies, Brighton.

Seccombe, I., Jackson, C., Patch, A., 1995. Nursing: The Next Generation. The Institute for Employment Studies, Brighton.

Seccombe, I., Patch, A., Stock, J., 1994. Workloads, Pay and Morale of Qualified Nurses in 1994. The Institute for Employment Studies, Brighton. 
Shields, M. A., Wheatley Price, S., 1999. Racial Harassment, Job Satisfaction and Intentions to Quit, Mimeo, University of Leicester.

Sloane, P. J., Williams, H., 1996a. Are “Overpaid” Workers really unhappy? A Test of the Theory of Cognitive Dissonance. Labour 10, 3-15.

Sloane, P. J., Williams, H., 1996b. Job Satisfaction, Comparison Income and Gender. Unpublished.

Steel, R., Ovalle, N., 1984. A Review and Meta-Analysis of Research on the Relationship between Behavioural intentions and Employee Turnover. Journal of Applied Psychology 69, 673-86.

Tai, T., Bame, S., Robinson, C., 1998. Review of Nursing Turnover Research, 1977-1996. Social Science and Medicine 12, 1905-24.

Tsang, M., Rumbereger, R., Levin, H., 1991. The Impact of Surplus Schooling on Work Productivity. Industrial Relations 30, 209-28.

UNISON, 1996. Over the Edge: UNISON's Evidence to the Nurses, Midwives and Health Visitors Pay Review Body. UNISON, London.

Ward, M. E., Sloane, P. J., 1999. Non-Pecuniary Advantages versus Pecuniary Disadvantages, Job Satisfaction among Male and Female Academics in Scottish Universities. Scottish Journal of Political Economy, forthcoming.

Warr, P., 1998. Well Being and the Workplace. In D. Kahneman, E. Diener and N. Schwartz (eds), Understanding Quality of Life: Scientific Perspectives on Enjoyment and Suffering. Russell Sage, New York. 
Table 1: The Distribution of Job Satisfaction by Job Aspect

\begin{tabular}{|c|c|c|c|c|}
\hline $\begin{array}{l}\text { Job Aspect } \\
\text { (Percentage) }\end{array}$ & Satisfied & $\begin{array}{c}\text { Neither Satisfied } \\
\text { or Dissatisfied }\end{array}$ & Dissatisfied & $\begin{array}{c}\text { Very } \\
\text { Dissatisfied }\end{array}$ \\
\hline Overall Job Satisfaction & $49.7(0.5)$ & $30.3(0.5)$ & $16.5(0.4)$ & $3.6(0.2)$ \\
\hline \multicolumn{5}{|l|}{ Pay and Advancement Related } \\
\hline Basic Pay & $31.9(0.5)$ & $34.3(0.5)$ & $26.9(0.5)$ & $7.0(0.3)$ \\
\hline Promotion Prospects & $17.3(0.4)$ & $36.9(0.5)$ & $29.1(0.5)$ & $16.8(0.4)$ \\
\hline Training Opportunities & $30.9(0.5)$ & $23.0(0.4)$ & $31.6(0.5)$ & $14.5(0.4)$ \\
\hline Security of Employment & $24.1(0.4)$ & $30.6(0.5)$ & $29.9(0.5)$ & $15.4(0.4)$ \\
\hline \multicolumn{5}{|l|}{ Workload Related } \\
\hline Present Workload & $30.4(0.5)$ & $28.1(0.5)$ & $32.0(0.5)$ & $9.5(0.3)$ \\
\hline Amount of Administration & $12.7(0.4)$ & $26.6(0.5)$ & $40.5(0.5)$ & $20.2(0.4)$ \\
\hline Time for Clinical Duties & $25.5(0.4)$ & $28.6(0.5)$ & $35.4(0.5)$ & $10.5(0.3)$ \\
\hline Qualified Nursing Support & $33.8(0.5)$ & $25.0(0.4)$ & $31.5(0.5)$ & $9.7(0.3)$ \\
\hline Auxiliary Nursing Support & $33.7(0.5)$ & $32.3(0.5)$ & $25.6(0.4)$ & $8.5(0.3)$ \\
\hline \multicolumn{5}{|l|}{ Work Environment Related } \\
\hline Involvement in Decision Making & $36.1(0.5)$ & $32.9(0.5)$ & $23.6(0.4)$ & $7.4(0.3)$ \\
\hline Flexibility of Working Hours & $45.6(0.5)$ & $30.5(0.5)$ & $16.7(0.4)$ & $7.3(0.3)$ \\
\hline Relations with Colleagues & $79.3(0.4)$ & $15.8(0.4)$ & $3.9(0.2)$ & $1.0(0.1)$ \\
\hline Relations with Patients & $87.4(0.4)$ & $9.8(0.3)$ & $2.4(0.2)$ & $0.4(0.1)$ \\
\hline Sample & \multicolumn{4}{|c|}{9625} \\
\hline
\end{tabular}

Note:

1. Standard errors in parenthesis. 
Table 2: The Percentage of Nursing Reporting an Intention to Quit

by Job Satisfaction Level and Job Aspect

\begin{tabular}{|c|c|c|c|c|c|}
\hline $\begin{array}{l}\text { Job Aspect } \\
\text { (Percentage) }\end{array}$ & Satisfied & $\begin{array}{c}\text { Neither Satisfied } \\
\text { or Dissatisfied }\end{array}$ & Dissatisfied & $\begin{array}{c}\text { Very } \\
\text { Dissatisfied }\end{array}$ & Gap \\
\hline Overall Job Satisfaction & $44.2(0.7)$ & $55.0(0.9)$ & $65.8(1.2)$ & $74.6(2.4)$ & $30.4^{*}$ \\
\hline \multicolumn{6}{|l|}{ Pay and Advancement } \\
\hline Basic Pay & $46.9(0.8)$ & $52.3(0.9)$ & $55.1(1.0)$ & $63.1(1.9)$ & $16.2^{*}$ \\
\hline Promotion Prospects & $44.7(1.2)$ & $49.7(0.8)$ & $53.2(0.9)$ & $63.1(1.2)$ & $18.4^{*}$ \\
\hline Training Opportunities & $45.5(0.9)$ & $50.0(0.4)$ & $54.8(0.9)$ & $63.8(1.3)$ & $18.3^{*}$ \\
\hline Security of Employment & $46.5(1.0)$ & $47.7(1.1)$ & $53.6(0.9)$ & $66.6(1.2)$ & $20.1^{*}$ \\
\hline \multicolumn{6}{|l|}{ Workload } \\
\hline Present Workload & $46.5(0.9)$ & $52.3(1.0)$ & $54.7(0.9)$ & $60.4(1.6)$ & $13.9^{*}$ \\
\hline Amount of Administration & $46.6(1.4)$ & $51.8(1.0)$ & $51.6(0.8)$ & $56.8(1.1)$ & $10.2^{*}$ \\
\hline Time for Clinical Duties & $47.2(1.0)$ & $51.5(1.0)$ & $53.7(0.9)$ & $60.2(1.6)$ & $13.0^{*}$ \\
\hline Qualified Nursing Support & $49.2(0.9)$ & $50.2(1.0)$ & $54.7(0.9)$ & $58.6(1.6)$ & $9.4^{*}$ \\
\hline Auxiliary Nursing Support & $50.0(0.9)$ & $50.2(0.9)$ & $54.8(1.0)$ & $59.4(1.7)$ & $9.4 *$ \\
\hline \multicolumn{6}{|l|}{ Work Environment } \\
\hline $\begin{array}{l}\text { Involvement in Decision } \\
\text { Making }\end{array}$ & $46.8(0.8)$ & $51.8(0.9)$ & $56.6(1.0)$ & $64.7(1.8)$ & $17.9^{*}$ \\
\hline Flexibility of Working Hours & $47.3(0.8)$ & $53.6(0.9)$ & $56.0(1.2)$ & $66.7(1.8)$ & $19.4 *$ \\
\hline Relations with Colleagues & $50.5(0.6)$ & $56.5(1.3)$ & $65.0(2.5)$ & $59.0(4.9)$ & $8.5^{*}$ \\
\hline Relations with Patients & $50.9(0.6)$ & $59.8(1.6)$ & $64.5(3.2)$ & $62.5(7.8)$ & $11.6^{*}$ \\
\hline Sample & \multicolumn{5}{|c|}{9625} \\
\hline
\end{tabular}

Note:

1. Standard errors in parenthesis.

2. 'Gap' is simply the difference in the percentage of nurses reporting an intention to quit between those who report satisfaction and those reporting to be very dissatisfied. '*' indicates that this difference is statistically significant at the $99 \%$ level of confidence. 
Table 3: Ordered Probit Estimates of the Determinants of Overall Job Satisfaction

\begin{tabular}{llc}
\hline Explanatory Variables & \multicolumn{2}{c}{ Overall Job Satisfaction } \\
\hline & Basic & Extended \\
\hline$\beta(|t|)$ & $\beta(|t|)$
\end{tabular}

\section{Individual characteristics}

Age 25-29

$-0.079(1.157) \quad 0.009(0.121)$

Age 30-34

$-0.088(1.239) \quad 0.029(0.404)$

Age 35-39

$-0.077(1.028) \quad 0.036(0.468)$

Age 40-44

$-0.009(0.111) \quad 0.107(1.369)$

Age 45-49

$0.079(1.014)$

$0.173(2.165)$

Age $>50$

0.297 (3.774)

0.381 (4.694)

Male

$-0.172(3.708)$

$-0.156(3.305)$

Asian

$-0.149(2.187)$

$-0.006(0.080)$

Black

-0.257 (4.488)

$-0.136(2.318)$

Other

$-0.027(0.600)$

$0.013(0.279)$

Married

0.088 (3.115)

$0.081(2.787)$

Degree

$-0.224(4.752)$

$-0.149(3.105)$

'A' level

$-0.132(2.856)$

$-0.094(2.002)$

'O' level

$-0.086(2.262)$

$-0.081(2.103)$

Number of children

$0.004(0.232) \quad 0.008(0.535)$

Number of children ${ }^{2} / 10$

\begin{tabular}{lcc}
\hline Wages and Hours & & \\
Grade I & $0.377(3.613)$ & $0.222(1.974)$ \\
Grade H & $0.407(5.962)$ & $0.243(3.409)$ \\
Grade G & $0.297(7.606)$ & $0.154(3.749)$ \\
Grade F & $0.132(3.352)$ & $0.107(2.652)$ \\
Grade D & $-0.098(2.715)$ & $-0.038(1.006)$ \\
Grade C & $-0.342(4.705)$ & $-0.045(0.586)$ \\
Relative wage (f) & $-0.101(2.786)$ & $-0.083(2.247)$ \\
Number of hours worked & $-0.010(4.919)$ & $-0.001(0.386)$ \\
Number of hours worked ${ }^{2} / 100$ & - & - \\
\hline Basic Job Characteristics & & \\
Enrolled nurse & $0.299(6.859)$ & $0.143(3.126)$ \\
Mentally handicapped & $-0.052(0.624)$ & $-0.109(1.282)$ \\
Medical / surgical & $0.037(0.762)$ & $0.082(1.637)$ \\
Midwifery & $-0.009(0.154)$ & $0.093(1.600)$ \\
Care of the elderly & $-0.061(1.042)$ & $-0.037(0.619)$ \\
Paediatrics & $0.223(3.407)$ & $0.247(3.688)$ \\
Primary and community & $0.155(2.692)$ & $0.214(3.611)$ \\
Other & $-0.083(0.955)$ & $0.038(0.422)$ \\
\hline
\end{tabular}


Table 3 (Continued)

\begin{tabular}{lcc}
\hline Currently doing post-basic training & $0.103(2.888)$ & $0.070(1.922)$ \\
Number of completed training spells & $-0.031(2.627)$ & $-0.031(2.498)$ \\
Tenure in current post (in months) & $-0.003(6.524)$ & $-0.002(4.602)$ \\
Tenure in current post ${ }^{2} / 100$ & $0.001(5.581)$ & $0.001(3.611)$ \\
Mix of earlies, lates and nights & $-0.157(4.018)$ & $-0.144(3.503)$ \\
Mix of earlies and lates (no nights) & $-0.186(3.874)$ & $-0.225(4.522)$ \\
Nights only & $-0.178(4.564)$ & $-0.181(4.466)$ \\
Flexitime/ Sharing/ Other & $0.007(0.148)$ & $0.075(1.548)$ \\
Member of trade union & $-0.045(0.855)$ & $-0.036(0.668)$ \\
\hline
\end{tabular}

\section{Extended Job Characteristics}

Actual $\neq$ Preferred shift

Has some control over shift/hours

Undertakes unpaid overtime

Undertakes tasks below grade

Acting up to higher grade

Plays an extended role

Grade not a fair reflection of duties

Assessor or mentor of students

Training encouraged at workplace

Has a second nursing job

\section{Work Values}

Helping others important

Flexibility of working hours important

Rewarding work important

Job security important

Promotion prospects important

$-0.026(0.798)$

Pay important

$-0.029(0.974)$

\begin{tabular}{lcc}
\hline Employer characteristics & & \\
General District Hospital & $-0.049(1.654)$ & $-0.072(2.252)$ \\
Family Health Service Authority & $-0.009(0.177)$ & $0.004(0.081)$ \\
Employer size / 100 (nursing staff) & $0.002(1.024)$ & $0.001(0.690)$ \\
Employer size / 1000 & - & - \\
Regional dummies (8) & YES & YES \\
\hline Threshold1 & -2.951 & -2.762 \\
Threshold2 & -1.944 & -1.666 \\
Threshold3 & -1.047 & -0.679 \\
Sample & 9625 & 9625 \\
Log likelihood $(0)$ & -10829.62 & -10829.62 \\
Log likelihood & -10412.50 & -9736.88 \\
Model $\chi^{2}$ & 834.24 & 2185.47 \\
Degrees of freedom $\left(\chi^{2}\right.$ test) & 51 & 67 \\
\hline
\end{tabular}

Notes: (see notes to Table 4) 
Table 4: Binary Probit Estimates of the Determinants of Intending to Quit the NHS

\begin{tabular}{|c|c|c|c|c|}
\hline \multirow[t]{2}{*}{ Explanatory Variables } & \multicolumn{2}{|c|}{ Model 1} & \multicolumn{2}{|c|}{ Model 2} \\
\hline & $\beta(|t|)$ & M.E & $\beta(|t|)$ & M.E \\
\hline Mean predicted probability & - & .523 & - & .522 \\
\hline \multicolumn{5}{|l|}{ Overall Job Satisfaction } \\
\hline Satisfied & $-0.815(10.454)$ & -0.316 & - & - \\
\hline Neither satisfied or dissatisfied & $-0.550(6.991)$ & -0.217 & - & - \\
\hline Dissatisfied & $-0.294(3.583)$ & -0.117 & - & - \\
\hline \multicolumn{5}{|l|}{ Job Satisfaction Components } \\
\hline Career advancement opportunities & - & - & $\begin{array}{c}-0.186 \\
(12.313)\end{array}$ & -0.074 \\
\hline Workload & - & - & $-0.040(2.622)$ & -0.016 \\
\hline Workplace relations & - & - & $-0.039(2.707)$ & -0.015 \\
\hline Pay & - & - & $-0.024(1.725)$ & -0.010 \\
\hline Qualified / auxiliary support & - & - & $0.015(1.019)$ & 0.006 \\
\hline \multicolumn{5}{|l|}{ Individual Characteristics } \\
\hline Age 25-29 & $0.126(1.556)$ & 0.050 & $0.116(1.431)$ & 0.046 \\
\hline Age $30-34$ & $-0.089(1.075)$ & -0.036 & $-0.093(1.121)$ & -0.037 \\
\hline Age $35-39$ & $-0.327(3.761)$ & -0.130 & $-0.332(3.822)$ & -0.132 \\
\hline Age $40-44$ & $-0.541(6.086)$ & -0.211 & $-0.548(6.181)$ & -0.214 \\
\hline Age $45-49$ & $-0.749(8.330)$ & -0.285 & $-0.757(8.419)$ & -0.288 \\
\hline Age $>50$ & $-0.356(3.946)$ & -0.141 & $-0.360(3.989)$ & -0.143 \\
\hline Male & $-0.010(0.199)$ & -0.004 & $0.002(0.041)$ & 0.001 \\
\hline Asian & $0.148(1.916)$ & 0.059 & $0.135(1.738)$ & 0.053 \\
\hline Black & $0.214(3.314)$ & 0.084 & $0.205(3.165)$ & 0.081 \\
\hline Other & $0.072(1.478)$ & 0.029 & $0.085(1.739)$ & 0.034 \\
\hline Married & $0.006(0.196)$ & 0.003 & $-0.002(0.062)$ & -0.001 \\
\hline Degree & $0.157(2.976)$ & 0.062 & $0.147(2.792)$ & 0.058 \\
\hline 'A' level & $0.124(2.402)$ & 0.049 & $0.118(2.277)$ & 0.047 \\
\hline 'O' level & $0.032(0.753)$ & 0.013 & $0.023(0.540)$ & 0.009 \\
\hline Number of children & $-0.247(6.438)$ & -0.098 & $-0.270(7.062)$ & -0.108 \\
\hline Number of children ${ }^{2} / 10$ & $0.502(3.995)$ & 0.200 & $0.558(4.448)$ & 0.222 \\
\hline \multicolumn{5}{|l|}{ Job Characteristics } \\
\hline Grade I & $0.115(1.022)$ & 0.046 & $0.211(1.889)$ & 0.083 \\
\hline Grade $\mathrm{H}$ & $0.133(1.942)$ & 0.053 & $0.172(2.343)$ & 0.068 \\
\hline Grade G & $0.073(1.810)$ & 0.029 & $0.090(2.077)$ & 0.036 \\
\hline Grade F & $0.010(0.233)$ & 0.004 & $0.032(0.731)$ & 0.013 \\
\hline Grade D & $-0.000(0.002)$ & $>0.000$ & $-0.011(0.258)$ & -0.004 \\
\hline Grade $\mathrm{C}$ & $-0.006(0.074)$ & -0.002 & $0.009(0.113)$ & 0.004 \\
\hline
\end{tabular}


Table 4 (Continued)

\begin{tabular}{|c|c|c|c|c|}
\hline Number of hours worked & $-0.020(3.119)$ & -0.008 & $-0.022(3.517)$ & -0.009 \\
\hline Number of hours worked ${ }^{2} / 100$ & $0.011(1.206)$ & 0.004 & $0.013(1.4230)$ & 0.005 \\
\hline Enrolled nurse & $-0.070(1.420)$ & -0.028 & $-0.099(2.022)$ & -0.040 \\
\hline Mentally handicapped & $0.071(0.722)$ & 0.028 & $0.094(0.966)$ & 0.038 \\
\hline Medical / surgical & $-0.140(2.507)$ & -0.056 & $-0.145(2.584)$ & -0.058 \\
\hline Midwifery & $-0.204(3.149)$ & -0.081 & $-0.222(3.415)$ & -0.088 \\
\hline Care of the elderly & $-0.043(0.637)$ & -0.017 & $-0.035(0.528)$ & -0.014 \\
\hline Paediatrics & $-0.089(1.205)$ & -0.036 & $-0.087(1.169)$ & -0.035 \\
\hline Primary and community & $-0.160(2.544)$ & -0.064 & $-0.160(2.531)$ & -0.063 \\
\hline Other & $-0.060(0.594)$ & -0.024 & $-0.051(0.514)$ & -0.021 \\
\hline Number of completed training spells & $-0.015(1.169)$ & -0.006 & $-0.008(0.606)$ & -0.003 \\
\hline Tenure in current post (in months) & $-0.001(1.587)$ & -0.001 & $-0.001(1.886)$ & -0.001 \\
\hline Tenure in current post ${ }^{2} / 1000$ & $0.001(2.597)$ & $>0.001$ & $0.001(2.965)$ & $>0.001$ \\
\hline \multicolumn{5}{|l|}{ Employer Characteristics } \\
\hline Size and type & YES & - & YES & - \\
\hline Regional dummies (8) & YES & - & YES & - \\
\hline Constant & $1.657(8.886)$ & & $1.132(6.659)$ & \\
\hline Sample & 9625 & & 9625 & \\
\hline Log likelihood (0) & -6663.10 & & -6663.10 & \\
\hline Log likelihood & -6206.63 & & -6213.85 & \\
\hline Model $\chi^{2}$ & 912.95 & & 898.50 & \\
\hline Degrees of freedom ( $\chi^{2}$ test $)$ & 49 & & 51 & \\
\hline
\end{tabular}

Notes:

1. Absolute t-statistics in parenthesis.

2. Omitted categories: very dissatisfied, age $<25$, female, white, no qualifications, grade E, registered general nurse, mental illness specialty.

3. The continuous variables were tested for appropriate functional form, and chosen to provide the best maximised likelihood. 


\section{IZA Discussion Papers}

No. Author(s)

21
J. Ondrich
C. K. Spiess
Q. Yang
G. G. Wagner

22
A. Million
R. Rotte
K. F. Zimmermann

23

T. Bauer

K. F. Zimmermann

24 K. F. Zimmermann

M. C. Burda

J. von Hagen

K. Konrad

F. Schneider

G. G. Wagner

K. Papps

R. Winkelmann

26

D. Enste

F. Schneider

27

E. Bratberg

$\varnothing$. A. Nilsen

28

U. Broll

K. P. Wong

D. J. Snower

30

J. Kluve

H. Lehmann

C. M. Schmidt

31

C. M. Schmidt

32

S.- A. Dahl

$\varnothing$. A. Nilsen

K. Vaage

A. Lindbeck

D. J. Snower

34
Title

Area

Date

The Liberalization of Maternity Leave Policy and

$1 / 3$

9/98

the Return to Work after Childbirth in Germany

The Economics of Hospital Trips and Health Care 3

$9 / 98$

Reform

Learning Efficiency of Economics Students

7

$9 / 98$

Petersberger Erklärung: Anstöße für eine

$1 / 3$

$10 / 98$

zukunftsgerichtete Arbeitsmarktpolitik

Unemployment and Crime: New Answers to an

Old Question

Increasing Shadow Economies All Over the

World - Fiction or Reality?

Transitions from School to Work: Search Time and Job Duration

Efficiency Wages and Futures Markets

$1 / 7$

$1 / 99$

Causes of Changing Earnings Inequality

Active Labor Market Policies in Poland:

$1 / 99$

Human Capital Enhancement, Stigmatization or Benefit Churning?

Persistence and the German Unemployment

Problem: Empirical Evidence on German Labor Market Flows

Work or Retirement? Exit Routes for Norwegian Elderly

Price Dynamics and Production Lags 
Is Job Stability in the United States Falling?

Reconciling Trends in the Current Population

1

Survey and Panel Study of Income Dynamics

The Effects of European Economic and Monetary

Union on Wage Behaviour

37 H. S. Buscher

Exchange Rate Volatility Effects on the German

Job Satisfaction within the Scottish Academic

Multi-Task Learning and the Reorganization of

Work

Empirical Findings on the Swiss Migration

Anatomy of Policy Complementarities

Household Characteristics, Ability and Education: Evidence from a Dynamic Expected Utility Model

The Effects of Development on Migration:

Theoretical Issues and New Empirical Evidence

Tenure-based Wage Setting

Overtime Work and Overtime Compensation in Germany

51 A. Barrett

P. J. O'Connell
J. Mayer
R. T. Riphahn

Ethnic German Migration After 1989 - Balance and Perspectives

Does Training Generally Work?

The Returns to In-Company Training

Fertility Assimilation of Immigrants: Evidence from Count Data Models

Inter-industry Wage Dispersion in Portugal: high 7 but falling 


\begin{tabular}{|c|c|c|c|c|}
\hline 55 & L. Goerke & $\begin{array}{l}\text { Value-added Tax versus Social Security } \\
\text { Contributions }\end{array}$ & 3 & $8 / 99$ \\
\hline 56 & $\begin{array}{l}\text { A. Lindbeck } \\
\text { D. J. Snower }\end{array}$ & $\begin{array}{l}\text { Centralized Bargaining and Reorganized Work: } \\
\text { Are they compatible? }\end{array}$ & $1 / 5$ & $9 / 99$ \\
\hline 57 & $\begin{array}{l}\text { I. N. Gang } \\
\text { K. F. Zimmermann }\end{array}$ & $\begin{array}{l}\text { Is Child like Parent? } \\
\text { Educational Attainment and Ethnic Origin }\end{array}$ & 1 & $9 / 99$ \\
\hline 58 & $\begin{array}{l}\text { T. Bauer } \\
\text { K. F. Zimmermann }\end{array}$ & Occupational Mobility of Ethnic Migrants & 1 & 9/99 \\
\hline 59 & $\begin{array}{l}\text { D. J. DeVoretz } \\
\text { S. A. Laryea }\end{array}$ & $\begin{array}{l}\text { Canadian Immigration Experience: } \\
\text { Any Lessons for Europe? }\end{array}$ & $1 / 2 / 3$ & $9 / 99$ \\
\hline 60 & $\begin{array}{l}\text { C. Belzil } \\
\text { J. Hansen }\end{array}$ & $\begin{array}{l}\text { Subjective Discount Rates, Intergenerational } \\
\text { Transfers and the Return to Schooling }\end{array}$ & 7 & $10 / 99$ \\
\hline 61 & R. Winkelmann & Immigration: The New Zealand Experience & 7 & $10 / 99$ \\
\hline 62 & A. Thalmaier & $\begin{array}{l}\text { Bestimmungsgründe von Fehlzeiten: Welche } \\
\text { Rolle spielt die Arbeitslosigkeit? }\end{array}$ & 3 & $10 / 99$ \\
\hline 63 & M. Ward & Your Everyday, Average Academic & 5 & $10 / 99$ \\
\hline 64 & M. Ward & $\begin{array}{l}\text { Salary and the Gender Salary Gap in the } \\
\text { Academic Profession }\end{array}$ & 5 & $10 / 99$ \\
\hline 65 & $\begin{array}{l}\text { H. Lehmann } \\
\text { J. Wadsworth } \\
\text { A. Acquisti }\end{array}$ & $\begin{array}{l}\text { Grime and Punishment: Job Insecurity and Wage } \\
\text { Arrears in the Russian Federation }\end{array}$ & 4 & $10 / 99$ \\
\hline 66 & $\begin{array}{l}\text { E. J. Bird } \\
\text { H. Kayser } \\
\text { J. R. Frick } \\
\text { G. G. Wagner }\end{array}$ & $\begin{array}{l}\text { The Immigrant Welfare Effect: Take-Up or } \\
\text { Eligibility? }\end{array}$ & 3 & $10 / 99$ \\
\hline 67 & $\begin{array}{l}\text { R. T. Riphahn } \\
\text { A. Thalmaier }\end{array}$ & $\begin{array}{l}\text { Behavioral Effects of Probation Periods: } \\
\text { An Analysis of Worker Absenteeism }\end{array}$ & $1 / 3$ & $10 / 99$ \\
\hline 68 & B. Dietz & $\begin{array}{l}\text { Ethnic German Immigration from Eastern Europe } \\
\text { and the former Soviet Union to Germany: the } \\
\text { Effects of Migrant Networks }\end{array}$ & 1 & $11 / 99$ \\
\hline 69 & M.-S. Yun & $\begin{array}{l}\text { Generalized Selection Bias and the Decomposition } \\
\text { of Wage Differentials }\end{array}$ & 7 & $11 / 99$ \\
\hline 70 & $\begin{array}{l}\text { I. N. Gang } \\
\text { F.L. Rivera-Batiz }\end{array}$ & $\begin{array}{l}\text { Immigrants and Unemployment in the European } \\
\text { Community }\end{array}$ & 1 & $11 / 99$ \\
\hline 71 & L. Goerke & The Wedge & 3 & $11 / 99$ \\
\hline 72 & $\begin{array}{l}\text { J. Fersterer } \\
\text { R. Winter-Ebmer }\end{array}$ & $\begin{array}{l}\text { Are Austrian Returns to Education Falling Over } \\
\text { Time? }\end{array}$ & 7 & $11 / 99$ \\
\hline 73 & $\begin{array}{l}\text { G. S. Epstein } \\
\text { S. Nitzan }\end{array}$ & The Endogenous Determination of Minimum Wage & 3 & $11 / 99$ \\
\hline
\end{tabular}


Knowing What Works: The Case for Rigorous

Entry Decision into Self-Employment from Transition Economies

80 J. C. van Ours

The Netherlands: Old Emigrants - Young 
An Evaluation of Public Employment Programmes in the East German State of Sachsen-Anhalt

97 A. Barrett

L. Husted

H. S. Nielsen

M. Rosholm

N. Smith

102 B. van der Klaauw

J. C. van Ours

K. Brännäs

104

S. Kohns

105
G. Brunello
C. Graziano
B. Parigi

106
L. Bellmann
S. Bender
U. Hornsteiner

107 J. C. van Ours

G. Ridder

108 J. Boone

J. C. van Ours

109 G. J. van den Berg

B. van der Klaauw

D. DeVoretz

C. Werner
Irish Migration: Characteristics, Causes and 1 Consequences

Industry Wage Differentials Revisited: A

Longitudinal Comparison of Germany and USA

Residential Location and Youth Unemployment:

\section{Transitions}

Immigrant Assimilation and Welfare Participation: 1/3/7

Do Immigrants Assimilate Into or Out-of Welfare?

Employment and Wage Assimilation of Male First 3 Generation Immigrants in Denmark

Estimation in a Duration Model for Evaluating

Different Skill Levels and Firing Costs in a

Matching Model with Uncertainty -

An Extension of Mortensen and Pissarides (1994)

Ownership or Performance: What Determines

Board of Directors' Turnover in Italy?

Job Tenure of Two Cohorts of Young German Men
1979 - 1990: An analysis of the (West-)German Employment Statistic Register Sample concerning multivariate failure times and unobserved heterogeneity

Fast Track or Failure: A Study of the Completion Rates of Graduate Students in Economics

Modeling Financial Incentives to Get Unemployed

Back to Work

Combining Micro and Macro Unemployment 
112 L. Bellmann

A Comparative Look at the Czech Republic

Innovations, Wages and Demand for

Heterogeneous Labour: New Evidence from a

Matched Employer-Employee Data-Set

113 R. Euwals

Do Mandatory Pensions Decrease Household

7

Savings? Evidence for the Netherlands

A. Medio

115 A. Cigno

F. C. Rosati

116 C. Belzil

117 S. Bender

A. Haas

C. Klose

118 M. A. Shields

M. E. Ward
An Explanation of International Differences in Education and Workplace Training

Why do Indian Children Work, and is it Bad for Them?

Unemployment Insurance and Subsequent Job Duration: Job Matching vs. Unobserved Heterogeneity

IAB Employment Subsample 1975-1995. Opportunities for Analysis Provided by the Anonymised Subsample

Improving Nurse Retention in the British National

5 Health Service: The Impact of Job Satisfaction on Intentions to Quit 